1940

\title{
Equine encephalomyelitis in man
}

Herman H. Brinkman

University of Nebraska Medical Center

This manuscript is historical in nature and may not reflect current medical research and practice. Search PubMed for current research.

Follow this and additional works at: https://digitalcommons.unmc.edu/mdtheses

Part of the Medical Education Commons

\section{Recommended Citation}

Brinkman, Herman H., "Equine encephalomyelitis in man" (1940). MD Theses. 789.

https://digitalcommons.unmc.edu/mdtheses/789

This Thesis is brought to you for free and open access by the Special Collections at DigitalCommons@UNMC. It has been accepted for inclusion in MD Theses by an authorized administrator of DigitalCommons@UNMC. For more information, please contact digitalcommons@unmc.edu. 
EQUINE ENCEPHALOMYELITIS IN MAN

$* * * * * *$

by

Herman $\mathrm{H}$. Brinkman

SENIOR THESIS

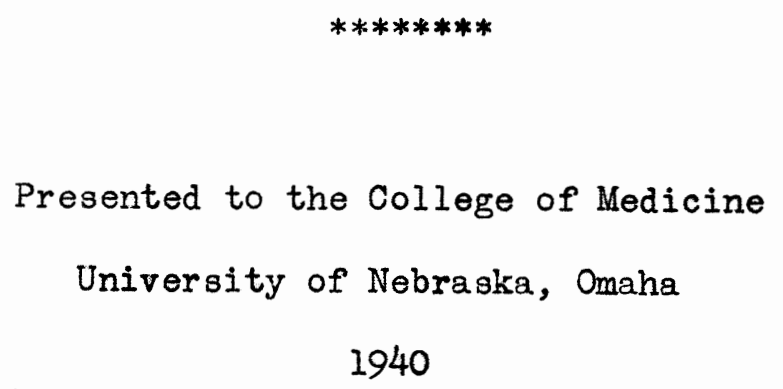


$\lcm{81081}$ 
TABLE OF CONTENTS






\section{INTRODUCTION}

The purpose of this paper is to present to the reader a correlation of the present status of equine encephalomyelitis with particular emphasis on the action of the equine virus on the human organism. Since the disease has only recently been proven to affect human beings it has been very difficult at times to find more than one authority to substantiate the theories and facts presented. Reference has been made to experimental evidence in animals where ever possible to clarify an understanding of this disease as it affects man. Much of the material on this disease needs further elucidation, however, it will be very interesting to note the progress in the study of the malady with particular reference to its transmission. 
HISTORY

History in Horses

It seems probable that equine encephalomyelitis has existed in the United States for at least a century and possibly longer. There is a possibility that the infection, which occurred in the west central states and was comronly known as the "Kansas Nebraska horse Plague" of 1912, might have been identical with the equine encephalomyelitis of today. The malady has frequently been confused with "forage poisoning" and "equine botulism".

It was not until 1930, when scattered cases of a peculiar disease affecting the central nervous system of horses and mules, that this disease began to attract the attention of live stock owners and veterinarians in the southern and the central part of the San Joaquin Valley of California. This condition began late in June or early in July and within one month spread to several hundred farms, totaling over 4,000 square miles, within an area of approximately 10,000 square miles. The epidemic reached its height in September but with the onset of cool nights no further cases were reported during December. No official records are available, but the morbidity of 5,970 cases with an approximate mortality of 2,955 as estimated by surveys of tallow works and other fairly dependable agencies was, despite the low economic value of the horse and mule, sufficiently severe to call for scientific inquiry. Interest was also aroused by the preliminary diagnosis of equine botulism. A hurried survey indicated 
that the diagnosis was incorrect irrespective of the supposed cures with specific mono or polyralent antitoxic serums. Tedious studies finally proved that the disease was due to a filterable virus and at this stage the malady disappeared from the valley (23).

With the onset of very hot weather in June the malady reappeared in 1931. Within a month it assumed epidemic proportions and reached its height in the Sacramento Valley between July Ilth and 20th, although cases were seen throughout California. Serious outbreaks were reported principally from the Sacramento Valley and Southern California. Localized outbreaks were observed in Nevada and Arizona. For a week or two the malady would rage in a certain section, then subside only to reappear in the same district. It is interesting that the horses on most of the farms which had one or many cases of encephalomyelitis during 1930 remained well in 1931, despite the fact that they were located in districts which suffered heavily during the most recent epidemic. As a rule, one horse in ten showed symptoms of the disease in the 1930 outbreak and rarely more than one or two animals of a group became affected. However, during 1931 higher proportions than this occurred. Thus on one ranch, five of the twenty-two animals were infected, on others seven of eight, three of nine, and five of fourteen respectively were observed. This peculiarity has been explained on the hypothesis that many horses contract the disease in such a mild form that it is not recognized (23). Again with 
the onset of cooler weather, in October 1931, the disease disappeared.

As a rule only animals kept on farms in more or less cultivated districts have contracted the disease. Nothing definite was known about the disease relative to its spread from farm to farm or how it occurred in periodic cyclical recurrances in extensive outbreaks within a year.

It was during the years of 1930 and 1931 when encephalomyelitis reached epidemic proportions in California that Meyer and his co-workers isolated the virus (22) and described the disease (23) and its pathology (20). The findings of these workers proved without a doubt that encephalomyelitis was a definite disease entity.

About the middle of August, 1938, cases of encephalomyelitis in horses were recognized in Massachusetts and it was soon ascertained that an epidemic of considerable proportions existed. The number increased with considerable rapidity, reaching a peak in the week ending August 27 th and rapidly declining thereafter. The disease appeared to be unusually fatal, very few recoveries being reported. It is estimated that well over 90 per cent of the horses have died. When cases were recognized in the East it was noted that the case fatality rate was twice as great east of the Appalachian Mountains. This led workers to suspect that a different virus was present in the East. Ten Broeck and and Merrell (31) have demonstrated that the Eastern and Western 
strains are immunologically different from each other and also different from the strain causing Borna disease in Europe. Coincident with recent severe epidemics of equine encephalomyelitis in the United States a similar disease was recognized in Venezuela. Portions of brains of horses dying of this disease were sent to Beck and Wyckoff (6) of the Lederle Laboratories for comparison with the northern types. When innoculated into guinea pigs and mice the Venezuelan virus produced symptoms similar to those of Eastern encephalomyelitis. The results of cross protection tests demonstrate that the Venezuelan virus is immunologically distinct from the western North American type of this disease but presumably has a minor heterophile factor common with the Eastern virus. For all practical purposes, therefore, three immunologically distinct epidemics of horse encephalomyelitis have been found: namely, Eastern, Western and Venezuelan. Human Encephalitis Due to Equine Virus As early as 1931 Meyer (23) suggested the possibility of humans contracting the disease. He noted in three individuals illnesses suspected of being due to the virus. The brief account of symptoms and findings in the fatal case is consistent with the clinical picture seen in the Massachusetts cases, particularly finding of polymorphonuclear leukocytes in the spinal fluid. On September 13, 1938, Dr. Fothergill (11) found the virus of the Eastern strain of equine encephalomyelitis in a patient who died at the Boston Children's Hospital. September 15, 1938, Dr. 
Webster (35) reported that he had recovered this same strain of virus on four patients. These cases are the first human infections definitely proved to be due to the equine virus (9). Since this time several other reports of human infection by the equine virus have been reported.

During the last week of August and the first two weeks of September, 1937, six cases of human encephalitis were reported from a county in northwestern Minnesota (8). All were in farmers, five of whom had had contact with sick horses. The sixth patient had had no contact with sick horses at the time of the onset of his illness. He had run a tractor on a farm in North Dakota not far from the Minnesota border. There was much equine encephalomyelitis in this locality. Two of the men had had contact with each other and with the same sick horses while threshing. The onset of their illnesses were August 29 and September 10. The others had not had any contact with one another or with any sick person. No other case occurred in the families of these six men. Blood was collected from three of the patients who recovered during January, 1938, and serums were forwarded to Dr. Carl Ten Broeck of the Rockefeller Institute for Medical Research (8). Under date of April 21, 1938, Dr. Ten Broeck reported that he had demonstrated neutralization of the Western strain of equine encephalomyelitis virus by the serum of one of the patients. As far as is known, this is the first time that neutralization of the virus of equine encephalomyelitis by human serum has been found. 
During August and September, 1938, Larimer and Wiesser (19) reported sixteen cases presenting features of meningitis but with unusual spinal fluid findings. There were ten males and six females. Despite the lack of proof, these cases were probably caused by an infective agent similar to that of epidemic equine encephalomyelitis, for the area from which these cases came has had an epidemic of equine encephalomyelitis and six of the men were definitely exposed to horses so affected.

In July, 1939, Dr. Fothergill (13) and his co-workers reported a death of a laboratory worker who was infected with the Western virus with which she was working. It was definitely proven that this case was due to Western equine virus infection (13). 
DEFINITION

Equine encephalomyelitis is an infectious disease due to the equine virus, characterized anatomically by marked edema of the brain and cord and clinically by a sudden onset with fever, headache, stiff neck and running a fulminating course, affecting man as well as animals. 


\section{ET IOLOGY}

The disease occurs in epidemic form in many localities but sporadic cases also make their appearance in many communities. In its epidemic behavior it closely resembles cerebro-spinal fever and anterior poliomyelitis. It prevails especially in the late summer and auturn of the year. It is a common disease among horses and certain fowls and not until 1938 has it been definitely proven that it also existed in man (11). No age seems to be exempt from this disease although it occurs with greater frequency in children. Dr. Feemster (9) reports that children under two years of age are particularly vulnerable and that they comprise 37 per cent of the cases which he observed. One-half of the cases were under five years of age and 69 per cent were under ten years of age. The cases are fairly evenly divided between the sexes.

\section{TABLE I (9)}

$$
\begin{gathered}
\text { Human Cases Under Investigation } \\
\text { Age and Sex }
\end{gathered}
$$

$$
\text { Suspected Cases }
$$

Male

Female

\begin{tabular}{|c|c|c|c|c|c|c|c|c|}
\hline \multirow[t]{5}{*}{ under } & 1 & 3 & 2 & 5 & 4 & 8 & 6 & 1 \\
\hline & 1 & 1 & 0 & 5 & 3 & 6 & 3 & 2 \\
\hline & 2 & 2 & 2 & 1 & 0 & 3 & 2 & 1 \\
\hline & 3 & 0 & 0 & 1 & 1 & 1 & 1 & 0 \\
\hline & 4 & 0 & 0 & 1 & 1 & 1 & 1 & 0 \\
\hline 0 & & 6 & 4 & 13 & 9 & 19 & 13 & 4 \\
\hline
\end{tabular}

Total

\section{Age Cases Deaths Cases Deaths Cases Deaths cases}


TABLE I (9)

(continued)

Human Cases Under Investigation

Age and Sex

Suspected Cases

Male

Female

Total

Age Cases Deaths Cases Deaths Cases Deaths Proved

$\begin{array}{llllllll}5 & -9 & 6 & 2 & 1 & 0 & 7 & 2\end{array}$

$\begin{array}{llllllll}0-9 & 12 & 6 & 14 & 9 & 26 & 15 & 6\end{array}$

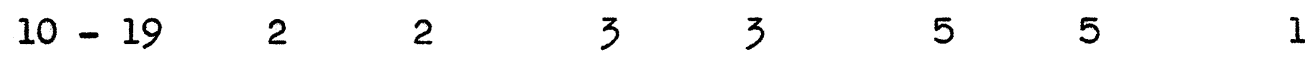

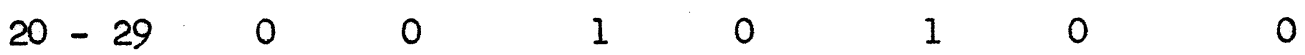

$\begin{array}{llllllll}30 & -39 & 0 & 0 & 0 & 0 & 0 & 0\end{array}$

$\begin{array}{llllllll}40 & -49 & 0 & 0 & 1 & 1 & 1 & 1\end{array}$

\begin{tabular}{|c|}
\hline 1 \\
\hline
\end{tabular}

$\begin{array}{llllllll}\text { Totals } & 18 & 11 & 20 & 14 & 38 & 25 & 8\end{array}$

Fothergill (11) reported the recovery of a filterable virus from the brains of children of a nature very similar to the equine encephalomyelitis virus. A sample was submitted by Dr. Fothergill to the pathological division of the Bureau of Animal Industry through Colonel R. A. Kelser, United States Army Veterinary Corps, on September 24, 1938.

The horses, one normal, one Eastern type immune and one Western type immune were injected with 1 cc.. of the prepared suspension on September 24, 1938. On September 25, in the late afternoon, the control horse had a temperature of $104.2^{\circ} \mathrm{F}$. and 
the Western immune horse had a temperature of $101.8^{\circ} \mathrm{F}$. On the days following, typical progressive symptoms of encephalomyelitis (congested "muddy" and icteric mucosae, maximum temperature of $105.4^{\circ} \mathrm{F}$. and $104.0^{\circ} \mathrm{F}$, depression, anorexia, dehydration with rapid loss of flesh, progressive weakness, paralysis and final collapse in recumbancy) developed in these animals. The control animal was sacrificed when completely prostrate the third day following innoculation. The animal immunized with the Western Virus died four days after the innoculation. The animal immunized with the Eastern virus developed typical severe encephalomyelitis but recovered without treatment and remained normal following the infection. (29) This experiment points out that the virus causing equine encephalomyelitis in these children when injected into horses produces symptoms which appear to be synonymous with equine encephalomyelitis. The fact that the Eastern immune hor se recovered would lead one to believe that the virus in question probably was the Eastern strain of the equine virus.

Veterinarians have reported the recurrence of equine encephalomyelitis in 16 horses during the 1931 epidemic in the San Joaquin Valley of California. A "recurrence" possibility of only 0.7 per cent would indicate that relapses are rare and that a clinical attack of the disease is productive of a high degree of immunity (23). Howill (3) corraborates this by stating that animals which recover from equine encephalomyelitis possess a 
high degree of immunity to further infection.

The existing cause was found to be a virus (23) which passes through bacteriological filters such as the Berkfeld $V$ and Seitz filters. Guinea pigs as well as horses have been successfully infected with such filtrates. In this respect it differs from Borna disease. There is some evidence that the virus passes through a 3.0 but not 3.5 or 4.0 per cent collodian ultra filter. Experiments with guinea pigs indicate that the virus is active in a dilution of 1:1000 brain suspension, but not in a dilution of $1: 10,000$. In the dry state the virulence is retained for at least five and a half months and when kept frozen remains active five weeks. It is very resistant to glycerine. Held in neutral 50 per cent glycerine at $41^{\circ} \mathrm{C}$. the brain tissues secured from an experimentally infected horse remained active twelve months (23). To date three distinctive strains of equine encephalomyelitis have been isolated: the Western strain (Meyer 1931-32) (23), the Eastern strain (Fothergill and his co-workers 1938) (11), and the Venezuelan strain (Beck and Wyckoff, 1938) (6). Ten Broeck and Merrell (31) demonstrated that the Eastern and Western strains were immunologically different from each other and the results of the cross protection tests of Beck and Wyckoff (6) showed that the Venezuelan virus was immunologically distinct from the Western North American type of this disease, but probably has a minor heterophile factor common with the Eastern virus. Although the mode of transmission of this disease is 
still a debatable question, the present epidemiologic and experimental evidence points to the spread of the infection by an insect vector rather than by contact (8).

Kelser (17) presents a report on the ability of mosquitoes to transmit the virus of equine encephalomyelitis to guinea pigs. The Aedes Aegypti mosquito was used. Commencing 48 hours after infection of the guinea pig a lot of 50 mosquitoes. were permitted to feed on the three guinea pigs innoculated with the equine virus. Successive lots of 50 mosquitoes were allowed to feed on the guinea pigs for 24 hours each until there were five lots of $48-72-96-120-144$ hour groups of infected mosquitoes. Two mosquitoes of the 48 hour group were killed and ground in physiological saline solution and injected intracutaneously into a guinea pig. This guinea pig died eight days later.

The 48 hour lot of infected mosquitoes were allowed to feed on two normal guinea pigs and both of them died of encephalomyelitis six days later. In like manner normal guinea pigs exposed to the $72-96$ and 120 hour groups of infected mosquitoes died from the sixth to the eighth day following exposure. This experiment should prove without doubt that mosquitoes are capable of transmitting the virus.

Experimentally the mosquitoes can be infected and transmit the virus to horses also. The Aedes Aegypti, A. sollicitans, A. Nigromaculis, A. Dorsalis, A. Albopictus Skuze, 
A. vexans and A. taeniorhynchus can transmit the Western strain; A. cantator and A. sollicitus the Eastern strain (17). To date no one has found infected mosquitoes in localities where equine encephalomyelitis is prevalent.

The work of Murphy (24) tends to show that most of the equine encephalomyelitis cases in the Omaha, Nebraska, area occurred on farms or in stables located on streams in depressed areas with trees or underbrush where mosquitoes are most likely to be harbored. A topography map of Omaha on which 400 cases of sick horses were plotted as found in Omaha and adjacent rural area reveals a pattern that supports the theory of a vector that can live and propagate in sheltered areas on or very near water courses. The absence of cases in areas in the vicinity of these water courses but on elevations suggests the mosquito as the agent that would be affected by wind.

Until recently it was supposed that the disease was limited largely to horses, but it now appears that the virus is probably harbored by other animals, including certain birds (32) (12), notably the Ring-necked Pheasant, pigeon, duck and goose. This fact adds valuable information concerning the distribution of this disease, and the designation "equine" becomes an unfortunate misnomer. Indeed, it may be seriously questioned whether the horse or other domestic animals play any essential role in assuring the perpetuation of this disease. The present demonstration of the natural occurrence of the infection in game birds and 
experimental evidence obtained by Remlinger and Bailey of the susceptibility of migratory birds to certain strains of encephalomyelitis suggest an easy mode for wide distribution of the virus. A search for spontaneous infection in migratory birds is indicated. Extensive surveys will be required in order to know just how widely the infection is spread in nature. It may be only under accidental circumstances or when the infection rises to a certain level that it overflows and becomes a serious problem as regards the horse and even the human being (32).

The present opinion is that these other animals are the primary reservoir and that man and horse are merely secondary hosts which accidentally become infected by mosquitoes which have previously bitten the animals harboring the virus. 


\section{PATHOLOGY (IN MAN)}

In order to get a clearer understanding of the pathological processes involved in this condition a brief review will be given with particular reference as to the nature and the action of viruses on the tissues involved.

The word virus means poison and before the relation of bacteria, fungi, spirochetes and protozoa to disease was recognized it was customary to use it as in a noncommittal manner to designate the causative agents responsible for certain maladies (28). The nature of viruses is still unknown (33) and there is a question if they are living organisms (28). Recent work has stimulated thought that they might be some inanimate substance generated in living cells under certain conditions. Viruses are usually referred to as intracellular parasites, which may vary in size and probably are not all of the same type (33).

It is important to realize that viruses do not behave as bacteria. Too frequently there is the assumption that viruses behave as bacteria, differing only in size (33).

Hurst (15) in a recent article has attempted to classify viruses as they affect different tissues. The following classification is the one he proposes:

1. Stricter neurotropes.

These viruses attack directly and destroy nerve cells but are without action on other cells. The virus is thought to pass up local nerves to 
the central nervous system and to multiply only in nervous tissue. The best known example is the virus of poliomyelitis.

2. Pantropic Viruses, Type I.

These viruses while definitely neurotopic also directly attach and produce specific lesions in cells derived from embryonic layers. In the nervous system they attack both entodermal and mesodermal structures.

3. Pantropic Viruses, Type II. Viruses in this group are neurotropic but outside the central nervous system they attack chiefly epithelial and blood vascular structures. In this group belongs the virus of equine encephalomyelitis.

Characteristically a phase of blood infection is followed by systemic immunity; in a certain proportion of cases encephalitis supervenes after the virus has disappeared from the blood. In the case of the equine encephalomyelitis virus, no evidence of neural spread is forth coming; during circulation in the blood the virus appears on the nasal mucosa and reaches the brain, probably by the perineural lymphatics and olfactory nerves. Since many sources of information on the pathology of this disease reveal nerve cell destruction it is interesting to 
note the process of nerve cell destruction and tissue reaction as outlined by Hurst (15). The essential pathology results from the effects of the virus on the cell and is characterized by hyperplasia and necrosis of the cells. The inflamatory reaction which is seen on post mortem is secondary and follows necrosis of the cells. This point has been made clear by experimental work. The inclusion bodies which are a pathologic sign of viral disease are thought to result from the association of the virus with the host (33).

The macroscopic appearance of the brain shows marked edema with the flattening of the convolutions and pinkish in color. The vessels of the pia-arachnoid are markedly engorged, the finer capillaries standing out as a delicate bright red network. The intensity of vascular engorgement increases from above downward, so that at the brain stem one has to look sharply to be sure there is no actual extravasation of blood. The membranes of the cervical cord show a definite, though not abrupt, transition from the fiery red of the pons and medulla to a degree of congestion more consistant with the upper surface of the hemispheres (36). Pressure cones were observed in the cerebellum (9). The subarachnoid spaces usually contain a small amount of slightly turbid, watery fluid in which no frank pus or fibrin can be demonstrated macroscopically. On cut sections the surfaces are of varying shades of light to dark salmon pink, against which the engorged vessels stand out prominently. 
On microscopic examination all parts of the brain stem show the same degree of involvement, with maximum changes in the basal ganglions, pons and medulla. The lower cord is rarely involved except for edema and congestion. The subarachnoid space contains much sero fibrinous coaglum, in the meshes of which are found large numbers of lymphocytes, monocytes and neutrophiles. The cells vary in proportion at various sites but in general lymphocytes predominate. The blood vessels which penetrate the parenchyma show profound perivascular cuffing with lymphocytes, neutrophiles, monocytes and rare plasma cells. The adventitial lymph spaces are filled with such cells to the extent that the surrounding brain tissue is invaded to some extent. The striking vascular phenomenon is the frequent predominance of neutrophiles in the perivascular accumulations. The arterial walls are 80 infiltrated with these cells that the condition could easily be classed as an acute arteritis (36). Fothergill (11) and his coworkers found many minute thrombi in the brain and various other organs on microscopic examination. No bacteria could be demonstrated in relation to these thrombi or to other lesions in the brain.

In the more severe cases, all layers of the cortex, basal ganglions, pons, medulla and other parts of the cervical cord show a marked diffuse infiltration with neutrophiles, occasional lymphocytes and monocytes and also discrete and confluent areas of profound necrosis infiltrated with similar cells. The degeneration 
of the neurones and neuroglia are not uniform in degree or distribution. The pyramidal layer in some instances presents minute foci of cellular infiltration and glial nodules, but in general the degeneration of the parenchyma is not marked but becomes more extensive in the ganglionic layer. The basal ganglions, pons and medulla present widely divergent degeneration of the nuclei and tracts. In general the median leminiscus, transverse fibers and pontile nuclei suffer most while lesions in the olivary nucleus occur only occasionally. The nuclei of the cranial nerves may be involved. Wesselhoeft and his co-workers (36) in examining one complete cord, report that both anterior and posterior horn cells of the cervical cord showed slight, but positive, involvement at all levels. Small focal lesions were noted in the cerebellar hemispheres, but no foci were noted in the nuclear layer. Occasional Purkenje cells were destroyed. The cellular degenerations were of virtually every conceivable type, from simple eccentricity and swelling of the nuclei to complete pyknosis, autolysis and neuronophagia. No inclusion bodies have been found by these men in the sections they examined.

In addition to the cord changes there is widespread congestion in the viscera. The abdominal and thoracic viscera and associated tissues present essentially the same microscopic changes, namely, a marked general hyperemia, varying degrees of anasarca, slight toxic changes in the liver and kidneys and a well defined lymphadenopathy and splenitis. 


\section{SYMPTOMS (IN MAN)}

The onset of equine encephalomyelitis in infants is sudden, with fever, irritability or drowsiness, cyanosis and convulsions. In older children and in one adult (9) the symptoms were of slower onset, from four to ten days. Headache, frontal in character, and dizziness were the first complaints in older patients. In two infants diarrhea preceded the other symptoms, while vomiting occurred in half of the cases. The majority of the patients showed continued tremors or muscular twitchings. Rigidity of the neck was a constant feature, as was a tense anterior fontanelle in the infants.

Larimer and Wiesser (19) reported an analysis of symptoms as they appeared in 16 cases. It is to be noted that there is no symptom which is characteristic of this condition and that any and all of the symptoms are those seen in various meningeal affections. (See Table II)

Table III outlines the various signs in this group of cases. It is to be noted that many of the signs are those not alone of meningeal but rather brain irritation. Likewise there is evidence of more than simple cortical irritation; levels as far as the optic thalmus were affected. 


\section{TABLE II}

Symptoms of Sixteen Reported Cases

Headache ........... 14

Stiff neck . . . . . . . 8

Vomiting ........... 8

Insomnia ........ 6

Restlessness ......... 6

Muscle pains......... 6

Nausea ........... 6

Photophobia ......... 5

Delirium . . . . . . . . 4

Dizziness .......... 4

Drowsiness .......... 4

Chills............. 3

Impaired hearing . . . . . . . 3

Mental confusion ....... . 3

Anorexia........... 3

Depression .......... 2

Ringing in ears ........ 2

Convulsions . . . . . . . . 2

Mumbling speech .......... 2

Apprehension . . . . . . . . 2

Sore throat, pain in abdomen, numbness, inability to swallow, earache and diarrhea occurred once. 
TABLE III

Signs of Sixteen Reported Cases

Fever ..................... 15

Neck rigidity . . . . . . . . . . . . . . 13

Positive Kernig's sign ................ 10

Patellar reflex diminished or absent . . . . . . . 7

Tremor .................... 6

Achilles tendon reflex diminished or absent ....... 5

Nystagmus . . . . . . . . . . . . . . . 4

Constricted pupil . . . . . . . . . . . . 4

Muscular rigidity . . . . . . . . . . . . 3

Dilated pupil .................. 3

Positive Babinski's sign ............... 3

Ankle clonus .................... 2

Positive Brudzinski's sign .............. 3

Facial weakness . . . . . . . . . . . . . . 2

Pharynx inflamed . . . . . . . . . . . . 2

Irregular respirations . . . . . . . . . . . . 2

Other signs noted were: Eyes deviated to right, eyes deviated upward, sluggish reaction to light, deviation of tongue, muscular twitching, hyperactive patellar reflex, stiffness in lower jaws, masked facies, urinary incontinence, hallucinations, laughing jag.

Evidence of an upper respiratory infection, that is pharyngitis and otitis media simplex, were found in a few of the 
cases at the Boston Children's Hospital and the Haynes Memorial Hospital at Boston. The suppression of the cutaneous reflexes was constant in the comatose patients, while the Kernig and kindred signs varied markedly. Facial palsies were seen in three cases, one of which had in addition a hemiplegia.

The course characteristically was short; the fever remaining high for about five days (19). The temperature ranged between $102^{\circ}$ and $104^{\circ}$ and in fatal cases continued to rise. No relationship between the severity of symptoms, physical signs, or spinal fluid changes and the mortality rate was noted. Temperatures in some cases reached $105^{\circ}$ until death became emminent. Where recovery took place the fever fell by lysis, becoming normal in four or five days.

The spinal fluid was under moderately increased pressure, average $240 \mathrm{~mm}$., hazy to ground glass in appearance; the cell count varied from 200 to 2,000 of which 60 to 90 per cent were polymorphonuclear. The total protein was high, 95 to 185 mg.; sugar was normal or slightly increased. Sugar determinations on various samples by the Folin Wu method gave an average of 104.5 milligrams (19). Wasserman reactions on the blood and spinal fluid were uniformly negative. No organisms were found on stained centrifuged smears, nor were there any growths on cultures.

The blood showed the same polymorphonuclear response. The white count varied from 14,600 to 65,900 ; the percentage of 
polymorphonuclears was from 75 to 90 . The counts above 35,000 were in children who also were afflicted with whooping cough.

When the patient lived over two or three days there was a drop in both spinal fluid and blood counts, with a change to the monomuclear type of cell.

Convulsions and muscular twitchings marked the course of the disease. In all infants a peculiar edema developed about the eyes and in the upper extremities. Cyanosis was marked in all cases.

When a patient survived the acute stage, the coma and the more or less rigidity of the muscles persisted for many days. An occasional patient showed gradual but slow improvement, returning apparently to normal. 


\section{DIAGNOSIS}

The only way in which a diagnosis of encephalomyelitis due to the equine virus can be made is by laboratory procedures (9). Clinically the disease is the same as any other encephalitis except that it tends to be more fulminating, has a shorter course and is characterized by a high mortality rate. One helpful point is the fact that early in the disease the cell count in the spinal fluid is not especially high (usually 200 to 1000 cells per cubic millimeter) with a preponderance of polymorphonuclear leukocytes during the first two or three days of the disease, but with rapid reversion to a preponderance of mononuclear cells as the count later decreases.

Unfortunately an etiologic diagnosis is not possible during the first four or five days of the illness, because at that time the virus is inaccessible, as it is present only in brain tissue, and neutralizing antibodies for the virus have not yet appeared in the blood stream. It has not yet been demonstrated how early these antibodies appear in the blood (16). Therefore, a 10-cc. sample of blood should be obtained as soon as a diagnosis of an encephalitis due to some other agent is made. It may eventually be discovered that neutralizing antibodies are present well before the end of the first week of illness. The virus is not found in the spinal fluid after the onset of the symptoms (19).

Since death often occurs within twenty-four to forty- 
eight hours after the case is first seen by the physician, the only way by which an etiologic diagnosis can be made in fatal cases is to isolate the virus from brain tissue removed post mortem. For virus isolation, the tissue must be placed in a neutral solution of 50 per cent glycerine made up in physiological salt solution. This solution will preserve the virus until it reaches the laboratory.

Where the patient survives as long as four or five days, or where complete recovery takes place, a 10-ce. sample of blood should be taken under aseptic precautions and put in a sterile tube. This tube should be mailed to a laboratory capable of performing tests for the presence of neutralizing antibodies in the blood.

The Massachusetts Department of Public Health has encouraged physicians to send in specimens of blood from suspected cases of equine encephalomyelitis for statistical purposes as well as for diagnosis. They have requested the co-operation of physicians to limit the specimens to those cases in which a presumptive diagnosis of infectious encephalitis is made. Since the laboratory procedures are both expensive and time consuming the following criterion has been established for the presumptive clinical diagnosis of the equine virus infection: it is not believed that a case which does not show a rise in temperature to at least $102^{\circ} \mathrm{F}$. can be due to the equine virus; in addition to the fever, there should be distinct signs of cerebral irritation, 
such as the presence of spasmotic contractions or actual convulsions or marked stupor or coma (16). 
COURSE

The course of the disease is characteristically short, the fever remaining high for about five days. There seems to be no relationship between the severity of the physical signs and symptoms of the disease (19). Wesselhoeft and his co-workers (36) report four deaths which have definitely been proven due to the equine virus. Three of these cases were of a fulminating nature with death occurring the third, fourth and fifth days of the disease. One case, a girl aged ten years, had a rather insidious onset with pains in the back of the legs two weeks before the onset of headache, drowsiness, rigidity of the neck and vomiting, which proceeded to coma and a temperature of $108^{\circ} \mathrm{F}$. Death occurred on the sixteenth day of the disease.

When a patient survived the acute stage, coma and more or less rigidity of the muscles persisted for many days. An occasional patient showed gradual but slow improvement, returning apparently to normal (9).

Some cases suspected of being due to the virus have made complete recoveries, but it appears that certain other cases will show paralysis, mental changes, and other permanent residuals. 


\section{PROGNOSIS}

Up until the present time the prognosis has been very unfavorable. Of thirty-eight cases under investigation by $\mathrm{Dr}$. Feemster (9) there was a mortality of sixty-five per cent. The high fatality rate corresponds with that found among horses. The morbidity among horses was low ( 3.5 per cent) but the case fatality was over 90 per cent. Until there are more definitely proven human cases no comprehensive statistical data, as to the morbidity and mortality of this disease, will be available. 


\section{PROPHYLAXIS}

Because it seems quite clear that equine encephalomyelitis is carried by mosquitoes, prevention of the disease by eliminating the varieties of mosquitoes which can carry the virus seems to be the most hopeful method of control. So far only mosquitoes belonging to one family (Aedes) have been able to act as a biological host of the virus. In all other varieties the virus promptly dies in the intestinal tract of the mosquito and cannot be obtained after two or three days have elapsed following feeding upon an infected animal. This would indicate that control measures could be limited to particular varieties of mosquitoes with particular reference to the Aedes group (16). Since one report has substantiated the probable accidental innoculation of a laboratory worker (13) in contact with the virus, it is quite possible that veterinarians and farmers could contract the disease by coming in contact with the virus while doing post mortems on horses that have died with the disease. Care must be exercised in protecting the individual from accidental innoculation. Although innoculation by accidental means has not definitely been proven it behooves any one who is working with the virus in any form to use means that will amply protect the individual from innoculation with the active virus.

For the past two years vaccines consisting of formolized extracts of virus diseased chick-embryo tissue have been employed on a large scale in the control of equine encephalomyelitis. 
From experience, under controlled laboratory conditions and from practical observations in the field, these vaccines proved highly effective. The factors responsible for this high response are not entirely clear (3).

Shahan and Giltner (30) have reported encouraging results with formolized horse brain in the protection of horses, and have obtained even more encouraging results with guinea pig brain-vaccine employed to vaccinate guinea pigs. Cox and Olitsky (7) have shown conclusively that high immunizing capacity of formolin-treated guinea pig and mouse brain-vaccines in which exhaustive tests failed to demonstrate active vims. The action of these vaccines was attributed to the high infections titer of the virus-diseased material formolized, $0.03 \mathrm{cc}$. of dilutions of 10-6 to 10-7 for guinea pig brain and 10-7 to 10-8 for mouse brain. Ten Broeck made the significant discovery that virus disease chick embryo-tissue under proper conditions gave a titer much greater than that previously reported (3). Wyckoff (37) found that a homogeneous heavy component possessing the properties of the virus could be isolated by ultra centrifugation from such diseased tissue furnished by $\mathrm{Dr}$. Ten Broeck but from no other. Experiments showed that by quantity ultra centrifugation a material (4) possessing a high degree of antigenicity could be obtained, small amounts of it protecting guinea pigs against large doses of virus given intracerebrally. It was found, however, that the unpurified formolized material exhibited a much 
greater capacity to protect guinea pigs and further study established the practical value of the crude vaccine in protecting not only guinea pigs and mice but horses as well. The fact that the vaccine has been so successful in animals has warranted its application to the problem of protection of man. A single "bivalent" vaccine has been employed in all of the work. The vaccine was prepared by mixing two batches of vaccine, one prepared with embryo diseased with the Eastern strain virus and the other with the Western strain, in equal parts and the resulting vaccine was thus bivalent. The standard horse protective dose of the vaccine prepared as described has been considered to be a total of $20 \mathrm{cc}$. given in two injections of $10 \mathrm{cc}$. each with an interval of one week. In humans the proportional adult dose was found to be approximately $4.0 \mathrm{cc}$. given in two doses with an interval of one week. The injection is given into the gluteal muscles thru a half-inch No. 26 hypodermic needle pushed deep into the tissue (3).

A group of one hundred men and women have been vaccinated with the crude formolized chick-embryo vaccines of the sort employed in the protection of horses against equine encephalomyelitis. Gener $a l$ and local reactions to the vaccine material were mild except in one instance in which muscular stiffness developed subsequent to vaccination.

Response to the vaccines as measured by serum neutral- 
izing antibody-content was high and apparently more rapid for the Western strain antigen than for the Eastern (3).

To what extent the presence of neutralizing antibodies can be employed as a criterion of immunity has not been determined. The antibody titers observed in man were as great as those of guinea pigs immunized with formolized brain-vaccines and found to be immune to severe intracerebral tests (25) with active virus. Recently, however, it has been reported (38) that vaccinated monkeys may possess high antibody titers and still lack immunity to the virus given intranasally. 


\section{TREATMENT}

Drs. Larimore and Wiesser who had sixteen cases under their care used the following management (19): treatment of these patients consisted chiefly of repeated spinal punctures and other means of reducing intracranial pressure. Fifty per cent glucose or sucrose given intravenously in amounts of fifty to one hundred cubic centimeters stood next to spinal puncture in value. Sulfanilamide was given an intensive trial but did not seem to alter the course of the disease. Morphine in large doses provided the best means of relief of headache and in some instances as much as one-fourth of a grain, repeated every two hours, was necessary. Moderately large doses of magnesium sulphate by mouth or rectum seemed to have a favorable effect. Convalescent serum was not tried but would deserve trial if one were sure of the diagnosis.

$$
\text { Meyer (23) reports the use of "hyperimmune" sera in }
$$

guinea pigs. He states that it will protect guinea pigs against fatal intracerebral or nasal administration of the virus if given one or even four days preceeding the infection. These experiments show that a therapeutic effect can be expected only during the febrile period when the virus is not yet fixed in the central nervous tissues.

Rivers (28) reports that once a virus has entered a cell no amount of anti serum brought in contact with the cell can injure the virus or hinder its activity. Such a phenomenon throws 
light on the clinical observations that the administration of convalescent or immune serum to an individual in whom signs and symptoms of a virus disease are already manifest is without value. 
SUMMARY

1. Equine encephalomyelitis is assumed to be a virus disease transmitted by a vector, probably the mosquito.

2. There are three distinct strains of the virus which are responsible for equine encephalomyelitis: namely, the Eastern, Western and Venezuelan strain.

3. Eight cases of human encephalomyelitis have proven to be due to the Eastern virus of equine encephalomyelitis. One case has been proven to be due to the Western virus.

4. Young children seem to be particularly vulnerable, adults are occasionally affected.

5. The case fatality is high; the mortality is about sixty-five per cent.

6. The reservoir may possibly be in certain fowls, notably the pheasant, duck, pigeon and goose and it is believed that the horse and man are merely infected accidentally.

7. A formolized chick-embryo vaccine has been used for the immunization of man as well as horses. The high antibody titer produced in human serum is not conclusive of its protective power.

8. The mode of transmission in nature has not been proven since no mosquito in the area of the equine encephalomyelitis epidemic among horses has been found to harbor the equine virus. 
1. Abramson, J. L.: Acute Lymphocytic Meningitis. Arch. Neurol. and Pyschiat., Vol. 31: 1235-1246, 1934.

2. Armstrong, $C$. and Wooley, J. G.: Benign Lymphocytic Choriomeningitis Laboratory Studies with Virus and their Possible Bearing on Infection in Man. J. A. M. A., Vol. 109: 410-412, 1937.

3. Beard, J. W.; Beard, D., and Finklestein, H.: Vaccination of Man against the Virus of Equine Encephalomyelitis. Jour. of Immun., Vol. 38, No. 2: 117-136, 1940.

4. Beard, J.W.; Sealy, W. C.; Finklestein, H.; and Wyckoff, R. W. G.: Immunization against Equine Encephalomyelitis with Chick Embryo Vaccines. Science, Vol. 87: $490,1938$.

5. Beck, C. E., and Wyckoff, R. W. G.: Antigenic Stability of Western Equine Encephalomyelitis Virus. Science, Vol. 88: $264,1938$.

6. Beck, C.E., and Wyckoff, R. W. G.: Venezuelan Equine Encephalomyelitis. Science, Vol. 88: 530, 1938.

7. Cox, H. R. and Olitsky, P. K.: Active Immunization of Guinea Pigs with Formolized Virus. Jour. of Exp. Med., Vol. 63: 745-765, 1936.

8. Eklund, C. M. and Blumstein, Alex: The Relation of Human Encephalitis to Encephalomyelitis in Horses. J. A. M. A., Vol. 111: 1734-1735, 1938.

9. Feemster, R. F.: Outbreak of Encephalitis in Man Due to the Eastern Virus of Equine Encephalomyelitis. Am. Jour. of Pub. Health, Vol. 28: 1403-1410, 1938.

10. Finkelstein, H.; Marx, W.; Bridges, W. H., and Beard, J. W.: Rate of Inactivation of Equine Encephalomyelitis Virus Relative to Concentration. Proc. Soc. Exper. Biol. Med., Vol. 39: 103-105, 1938.

11. Fothergill, L. D.; Dingle, J. H., and Farber, Sidney: Human Encephalitis Caused by the Virus of the Eastern Variety of Equine Encephalomyelitis. New Eng. Jour. of Med., Vol. 219: 411, 1938. 
12. Fothergill, L. D., and Dingle, J. H.: A Fatal Disease of Pigeons Caused by the Virus of the Eastern Variety of Equine Encephalomyelitis. Science, Vol. 88: 549$550,1938$.

13. Fothergill, L. D.; Holden, M., and Wyckoff, R. W. G.: Western Equine Encephalomyelitis in a Laboratory Worker. J. A. M. A., Vol. 113: 206-207, 1939.

14. Hurst, E. W.: Experimental Poliomyelitis. Jour. of Path. and Bact., Vol. 32: 457-476, 1929.

15. Hurst, E. W.: Newer Knowledge of Virus Diseases of the Nervous System. Brain, Vol. 59: 1-59, 1936.

16. Jakmauh, P. J. and Feemster, R. F.: Laboratory Diagnosis of Encephalitis Due to the Equine Virus. The New Eng. Jour. of Med., Vol. 221: 653-655, 1939.

17. Kelser, R. A.: Mosquitoes as Vectors of the Virus of Equine Encephalomyelitis. J. Am. Vet. M. A., Vol. 82: $767-771,1933$.

18. Kelser, R. A.: Transmission of the Virus of Equine Encephalomyelitis of Aedes Taeniorhynchus. J. Am. Vet. M. A., Vol. 92: 195-203, 1938.

19. Larimer, R. N. and Wiesser, E. G.: Human Equine Encephalomyelitis. Jour. of Iowa State Med. Soc., Vol. 19: 287-288, 1939.

20. Larcell, O.; Haring, C. M., and Meyer, K. F.: Histologic Studies of the Central Nervous System Following Encephalomyelitis (in horses). Am! J. Path., Vol. 10: 361-374, 1934.

21. Matheson Commission: Epidemic Encephalitis - Third Report. P. 20-22. New York, Columbia University Press, 1939.

22. Meyer, K. F.; Haring, C. M., and Howitt, B.: The Etiology of the Epizootic Encephalomyelitis of Horses in the San Joaquin Valley. Science, Vol. 74: 227-228, 1931.

23. Meyer, K. F.: Equine Encephalomyelitis. Annals of Int. Med., Vol. 6, Pt. 1: 645-654, 1932.

24. Murphy, J. H.: Comparative Epidemiology of Encephalomyelitis and Poliomyelitis. Nebr. State Med. Jour., Vol. 24, No. 12: $453,1939$. 
25. Olitsky, P. K. and Hartford, C. G.: Intraperitoneal and Intracerebral Routes in Serum Protection Tests with Virus; Mechanism Underlying Protective Power by Two Routes. Jour. Exper. Med., Vol. 68: 761-777, 1938.

26. Olitsky, P. K. and Hartford, C. G.: Intraperitoneal and Intracerebral Routes in Serum Protection Tests with Virus: Comparison of Two Routes of Protection Tests. Jour. of Exper. Med., Vol. 68: 779-787, 1938.

27. Olitsky, P. K. and Morgan, I. M.: Protective Antibodies Against Virus in Serum of Lab Workers. Proc. Soc. Exp. Biol. and Med., Vol. 41: 212, 1939.

28. Rivers, T. H.: Recent Advances in the Study of Viruses and Viral Diseases. J. A. M. A., Vol. 107: 206-210, 1936.

29. Schoenning, H. W.; Shahan, M. S., and Giltner, L. T.: Equine Encephalomyelitis Produced by Innoculations of Human Encephalitis Virus. Science, Vol. 88: 409-410, 1938.

30. Shahan, M. S. and Giltner, L. T.: Infection and Immunity. Jour. Am. Vet. M. A., Vol. 84: 928-934, 1934.

31. Ten Broeck, C., and Merrill, M. H.: A Seriological Difference Between Eastern and Western Equine Encephalomyelitis Virus. Proc. Soc. Exper. Biol. and Med., Vol. 31: 217-220, 1933.

32. Tyzzer, E. E.; Sellards, A. W., and Bennett, B. L.: Occurrence in Nature of "Equine Encephalomyelitis" in the Ring-necked Pheasant. Science, Vol. 88: 505-506, 1938.

33. Young, R. H.: Virus Diseases of the Nervous System. Nebr. State Med. Jour., Vol. 23: 220-223, 1938.

34. Viets, H. R., and Warren, S.: Acute Lymphocytic Meningitis. J. A. M. A., Vol. 108: 357-361, 1937.

35. Webster, L. T., and Wright, F. H.: Recovery of Eastern Equine Encephalomyelitis Virus from Brain Tissue of Human Cases of Encephalitis in Man. Science, Vol. 88: 305-306, 1938.

36. Wesselhoeft, C.; Smith, E. C., and Branch, E. F.: Human Encephalitis. J. A. M. A., Vol. 111: 1735-1741, 1938. 
37. Wyckoff, R. W. G.: Ultra Centrifugal Concentration of Homogeneous Heavy Component from Tissues Diseased with Encephalomyelitis. Proc. Soc. Exp. Biol. and Med., Vol. 36: 771-773, 1937.

38. Wyckoff, R. W. G., and Teasar, W. C.: Equine Encephalomyelitis in Monkeys. Jour. of Immun., Vol. 37: $329,1939$. 